\title{
Volcanic Caves as Priority Sites for Astrobiology Science
}

\section{A White Paper submitted to the Decadal Survey on Planetary Science \& Astrobiology}

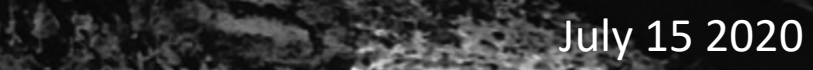

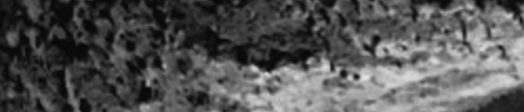

13.

ind

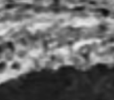

Lead Author:

Jennifer G. Blank

NASA Ames Research Center | Blue Marble Space Institute of Science jennifer.g.blank@nasa.gov; jen@bmis.org ; Tel. 415-902-4989

Contributing Authors:

Ali-akbar Agha-mohammadi, NASA Jet Propulsion Laboratory

Ernest R. Bell, Jr., University of Maryland, College Park

David A. Crown, Planetary Science Institute

Benjamin Morrell, NASA Jet Propulsion Laboratory

Christopher J.S. Patterson, McGill University

Kyle Uckert, NASA Jet Propulsion Laboratory

Patrick L. Whelley, University of Maryland, College Park | NASA Goddard Space Flight Center 
We have the technological capability- today- to map and explore mines and caves on Earth. The purpose of this white paper is to urge NASA's support for development of technology needed to enter a planetary cave with a scientific payload for life detection. In the next pages, we tabulate the current state of technology \& review the main challenges associated with:

1) remote characterization of volcanic caves, 2) subsurface exploration vehicles with advanced subsurface autonomy + communications + operations capabilities, 3) sensor systems developed for life and biosignature identification. Let's go to volcanic caves on Mars!

\section{MOTIVATION}

Humans have looked for extraterrestrial biosignatures on the surfaces of other planets and moons. These surfaces are often exposed to conditions and processes that exceed the physical limits of life, e.g., intense cosmic radiation, impact events, and large thermal extremes, that would render difficult the preservation of biosignatures over geologic time.

Planetary caves might provide protection from cosmic radiation, small-scale impact events, and have relatively stable thermal environments. These characteristics may well permit preservation of biosignatures over long periods of time and make them a prospective astrobiology target for biosignatures beyond Earth (Boston et al., 2001; Léveillé \& Datta, 2010; Martins et al., 2017). A cave with natural openings offers direct access to the subsurface without drilling and deeper penetration into subsurface materials than could be obtained from a rover, landed platform, or penetrator launched from orbit. However, current technological and mechanical limitations associated with ingress and navigation, and communication and/or data retrieval make their exploration challenging.

Caves form through a number of processes, but those on the Moon and Mars identified using satellite data are thought to be lava tubes. On Earth, most lava tubes are associated with basaltic lava, a material predicted to be ubiquitous on all rocky planets. On the Moon and Mars, hundreds of vertical collapse pits have been identified using a number of remote sensing approaches (Greeley, 1971; Cushing et al., 2015; 2007; Haruyama et al., 2009; 2017); many of these may be skylights providing direct access to intact caves, some of which may be be substantially larger than those found on Earth due to the combination of lower gravity and higher eruption rates on these smaller planetary bodies (e.g., Blair et al., 2017). Future planetary astrobiology missions would be well-served to include lava tubes as a high-priority target for investigation.

NASA's SMD currently supports several Earth-based planetary cave analog investigations through its PSTAR (Planetary Science and Technology through Astrobiology Research) program; a table summary of these efforts is also included. We conclude with mention of current and ongoing technology developments both internal and external to NASA that could advance planetary cave identification, access, and exploration.

\section{REMOTE IDENTIFICATION OF LAVA TUBES}

Lava tubes are generated from basaltic eruptions, when lava discharging from a volcanic vent or fissure forms solidified conduits that insulate the molten flow thermally from the surface and delay its cooling as the streaming material moves down slope. Ultimately, the lava drains from the conduit, leaving behind a hollow tube (e.g., Peterson et al., 1994). Lava caves form at the surface initially, extending from flow levees along a principal flow channel, and then evolve into near-surface features as a roof is generated; fully formed lava caves are typically less than a few 
meters below the surface of the lava flow. Continued volcanism can lead to erosion or burial of older caves beneath younger eruptions, and lava caves and their remnants can exist at substantial $(>1 \mathrm{~km}$ ) depths on Earth though the majority extend relatively shallow ( $<100 \mathrm{~m})$ depths, only. These caves are most often found through the presence of skylights and collapse pits, where a portion of the lava cave roof has collapsed and exposed the lava cave to the surface; skylights provide surface access to lava caves and help mark their presence.

Near-surface lava tubes can be detected using a variety of techniques (Table 1), including:

- Visual detection of exposed skylights or roof-collapse pits using high-resolution surface imaging methods

- Detection of topographic irregularities to identify possible lava cave openings from surface brightness (albedo) profiles

- Thermal measurements and analysis to detect temperature contrasts between cave openings and the surrounding surface rocks

- Ground-penetrating radar measurements to detect the presence of shallow cavities

- High-precision gravity methods to detect the presence of shallow volcanic caves

- Magnetic ground level surveys to detect reductions in magnetic strength above void spaces

Table 1 Examples of Recent Projects that focus on Volcanic Cave Identification from Satellite Orbit or Aircraft using Remote-Sensing Techniques

\begin{tabular}{|c|c|c|c|}
\hline Technique & Project/Mission & Key Observations & References \\
\hline \multirow{3}{*}{$\begin{array}{l}\text { High-res } \\
\text { imaging of } \\
\text { surface } \\
\text { openings }\end{array}$} & Lunar Reconnaissance Orbiter & $\begin{array}{l}\text { Subsurface voids discovered with oblique imaging may } \\
\text { be extensive lava cave systems, or represent collapses } \\
\text { created as magma drained }\end{array}$ & $\begin{array}{l}\text { Allen (2009); } \\
\text { Robinson et al. } \\
\text { (2012) }\end{array}$ \\
\hline & SELENE & $\begin{array}{l}\text { Discovered } 65 \mathrm{~m} \text { diameter, } 80-90 \mathrm{~m} \text { vertical hole in a } \\
\text { lava cave with a } \geq 370 \mathrm{~m} \text { covered conduit }\end{array}$ & $\begin{array}{l}\text { Haruyama et al. } \\
\text { (2009) }\end{array}$ \\
\hline & $\begin{array}{l}\text { Mars Reconnaissance Orbiter; } \\
\text { HiRISE Camera }\end{array}$ & $\begin{array}{l}\text { Discovered several volcanic skylights and associated } \\
\text { lava tube features in Tharsis region of Mars. }\end{array}$ & $\begin{array}{l}\text { Daga et al. } \\
\text { (2013) }\end{array}$ \\
\hline $\begin{array}{l}\text { Magnetic } \\
\text { Anomalies }\end{array}$ & $\begin{array}{l}\text { Lava Beds Nat'I Monument, } \\
\text { USA }\end{array}$ & $\begin{array}{l}\text { Correlated magnetic anomalies \& surface } \\
\text { geomorphology to characterize terrestrial lava tubes; } \\
\text { compared with void lidar mapping inside cave }\end{array}$ & $\begin{array}{l}\text { Bell et al. } \\
(2020)\end{array}$ \\
\hline $\begin{array}{l}\text { Surface } \\
\text { brightness }\end{array}$ & $\begin{array}{l}\text { Laboratory experiments and } \\
\text { modeling }\end{array}$ & Models to evaluate brightness profiles of pit craters & $\begin{array}{l}\text { Jung et al. } \\
\text { (2016) }\end{array}$ \\
\hline \multirow{3}{*}{$\begin{array}{l}\text { Thermal IR \& } \\
\text { Context } \\
\text { Images }\end{array}$} & $\begin{array}{l}\text { Atacama Desert, Chile; Mohave } \\
\text { Desert, USA }\end{array}$ & $\begin{array}{l}\text { Contrast between surface temperatures and near- } \\
\text { constant cave interior temperatures }\end{array}$ & $\begin{array}{l}\text { Wynne et al. } \\
\text { (2008) }\end{array}$ \\
\hline & $\begin{array}{l}\text { Mars Odyssey Thermal } \\
\text { Emission Imaging System }\end{array}$ & $\begin{array}{l}7 \text { candidate cave skylights located with diam. } 100-225 \\
\text { m and predicted minimum depths } \geq 68-130 \mathrm{~m}\end{array}$ & $\begin{array}{l}\text { Cushing et al. } \\
\text { (2007), (2015) }\end{array}$ \\
\hline & $\begin{array}{l}\text { Mars Odyssey Thermal } \\
\text { Emission Imaging System }\end{array}$ & $\begin{array}{l}\text { Analysis of T changes of day/night for } 7 \text { cave } \\
\text { candidates }\end{array}$ & $\begin{array}{l}\text { Jung et al. } \\
\text { (2014) }\end{array}$ \\
\hline $\begin{array}{l}\text { Thermal } \\
\text { inertia }\end{array}$ & LRO Diviner Lunar Radiometer & $\begin{array}{l}\text { Thermal inertia and Tmax/Tmin ratio maps and imaging } \\
\text { were used to identify } 4 \text { lunar sites associated with } \\
\text { skylights }\end{array}$ & Slank (2016) \\
\hline $\begin{array}{l}\text { Ground- } \\
\text { penetrating } \\
\text { radar }\end{array}$ & SELENE Lunar Radar Sounder & $\begin{array}{l}\text { Distinctive echo patterns evidence for the existence of } \\
\text { a lava cave - and correlated with gravity mass } \\
\text { deficiencies detected by GRAIL }\end{array}$ & $\begin{array}{l}\text { Kaku et al. } \\
\text { (2017); Sood et } \\
\text { al. (2016) }\end{array}$ \\
\hline $\begin{array}{l}\text { High } \\
\text { precision } \\
\text { gravity }\end{array}$ & GRAIL & $\begin{array}{l}\text { Relatively large linear features detected in the vicinity } \\
\text { of known skylights }\end{array}$ & $\begin{array}{l}\text { Chappaz et al. } \\
\text { (2017) }\end{array}$ \\
\hline $\begin{array}{l}\text { Drone recon } \\
\text { in situ }\end{array}$ & $\begin{array}{l}\text { Laboratory and field } \\
\text { experiments }\end{array}$ & $\begin{array}{l}\text { A drone can fly in advance of a rover to visually check } \\
\text { for caves with high resolution imaging as an initial } \\
\text { phase of a planetary mission }\end{array}$ & $\begin{array}{l}\text { Nilsson et al., } \\
\text { (2018); Saski et } \\
\text { al. (2020) }\end{array}$ \\
\hline
\end{tabular}




\section{PHYSICAL EXPLORATION OF LAVA CAVES}

A variety of robotic approaches have been proposed to overcome key obstacles related to entering and navigating inside caves, including:

- Entry from the surface down into the lava cave system through a skylight - these entrances often include a large vertical drop (from a few meters to $>50 \mathrm{~m}$ )

- Traversing an irregular floor surface and/or over large blocky obstacles

- Operations in darkness.

- Autonomous operation and localization (loss of direct communications to surface assets). In addition to traditional wheeled rovers, robotic vehicles using biomimicry offer alternative locomotion in challenging subsurface terrain. Prototypes include fleets of coordinating robotic ants, butterflies, dragonflies, and spiders optimized for relay communications away from a control center. Recent cave robotic innovations are centered around a few themes, sorted by modality in Table 2. Robotics technologies that link perception, navigation, mapping and decision making have made great advances. This means that previously impractical approaches for exploring cave environments are near-future possibilities.

\section{Table 2: Robotic Mobility Systems for Subsurface Exploration of Lava Tubes}

\begin{tabular}{|c|c|c|}
\hline $\begin{array}{l}\text { Robotic } \\
\text { Modality }\end{array}$ & Description & Examples \\
\hline $\begin{array}{l}\text { Micro- } \\
\text { swarms }\end{array}$ & $\begin{array}{l}\text { Simple, mass-produced, redundant, teams. Dropped, shot, or hopped into cave } \\
\text { entrances. Redundancy provides parallel exploration and risk reduction. Each robot } \\
\text { in swarm has low science capability. }\end{array}$ & $\begin{array}{l}\text { Pit-bots (Thangavelautham et } \\
\text { al., 2014), SphereX (Kalita et al., } \\
\text { 2017), HedgeHog (Hockman et } \\
\text { al., 2016), Tensegrity (Aldrich et } \\
\text { al., 2006; Gebara et al., 2019) }\end{array}$ \\
\hline Rovers & $\begin{array}{l}\text { Drive over blocky collapse ramps to access caves. Technology includes inflatable } \\
\text { wheels, tandem tethered teams, and pneumatic hopping. Rovers provide superior } \\
\text { payload ratio and simple concept of operations. While traditionally rovers were } \\
\text { limited to the ground plane, the advances in Al, traversability, and autonomy allows } \\
\text { the new generation rovers to be able to negotiate more obstacle-laden terrains and } \\
\text { traverse narrow passages that were traditionally non-traversable by rovers. }\end{array}$ & $\begin{array}{l}\text { Sandflea (Boston Dynamics) } \\
\text { UZUME (Furutani, 2016), } \\
\text { Hakuto (Walker et al., 2015), } \\
\text { CoSTAR cave robots (Agha et al., } \\
\text { 2019), } \\
\text { ACE (Otsu et al., 2019) }\end{array}$ \\
\hline $\begin{array}{l}\text { Cable- } \\
\text { deployed }\end{array}$ & $\begin{array}{l}\text { Use tethers and cables to enter vertically through skylights/openings. Descend via } \\
\text { rappelling or a Tyrolean deployment. Surface tether infrastructure-to-surface } \\
\text { introduces complexity but can provide power and communications for robots inside } \\
\text { cave. Possibility to lower large payloads to lava tube floors. }\end{array}$ & $\begin{array}{l}\text { Axel (Nesnas et al., 2008) } \\
\text { Cliffbot (Paulsen et al., 2005), } \\
\text { Tyrobot (Wong et al., 2015), } \\
\text { DuAxel (Nesnas et al., 2012) }\end{array}$ \\
\hline Climbers & $\begin{array}{l}\text { Negotiate blocky hazards and climb cave walls and ceilings with gripping limbs. } \\
\text { Enables long-duration access to interesting features on cave walls \& ceiling, but can } \\
\text { carry only moderate payload. Risky due to inherent lack of stability. }\end{array}$ & $\begin{array}{l}\text { Lemur } 3 \text { (Parness et al., 2017) } \\
\text { Geckobots (Sitti et al., 2003) }\end{array}$ \\
\hline $\begin{array}{l}\text { Legged and } \\
\text { multi- } \\
\text { limbed } \\
\text { platforms }\end{array}$ & $\begin{array}{l}\text { Negotiate blocky hazards, high slopes, and mobility-stressing environment; ability to } \\
\text { self-right and stand-up in case of losing stability. Able to carry moderate to large } \\
\text { payloads. }\end{array}$ & $\begin{array}{l}\text { SPOT (Boston Dynamics), } \\
\text { RoboSimian (Karumanchi et al., } \\
\text { 2017), CoSTAR cave robots } \\
\text { (Agha et al., 2019) }\end{array}$ \\
\hline Flyers & $\begin{array}{l}\text { Fly into caves through openings. Propulsive or rotorcraft. Drones avoid all obstacles } \\
\text { and have good vantage points at the center of voids for scientific observation. Range- } \\
\text { limited or inefficient in thin planetary atmospheres. Limited payload capacity }\end{array}$ & $\begin{array}{l}\text { Cave drones (Tabib, 2020), Mars } \\
\text { Helicopter Ingenuity will fly on } \\
2020 \text { but no plans to explore a } \\
\text { cave, CoSTAR cave robots \& } \\
\text { drones (Agha et al., 2019) }\end{array}$ \\
\hline
\end{tabular}

As our advances in autonomous mobility systems have grown exponentially, exploration technologies have matured sufficiently to enable near-future robotic missions to planetary caves (and voids). Progress has been expedited by synergistic collaboration between the 
expanding commercial space sector, mining companies, and government agencies. Most relevant to the subject of this white paper, the US Department of Defense has invested in autonomy technology demonstrations through its current Defense Advanced Research Projects Agency (DARPA) Subterranean (Sub-T) Challenge Program, (2018-present), in which NASA-led teams have been active participants and challenge winners (Agha et al., 2019). Thus autonomy capabilities, developed and tested for resource characterization and acquisition in terrestrial settings, have a second utility in the search for signs of past and/or extant life. In particular, there have been significant advances in autonomous traversability, perception, autonomous mission planning and decision-making, and communication for exploring subsurface voids. Below we summarize and reference some of this work.

(i) Autonomous traversability: Capabilities to model, negotiate, and move over largely unknown and potentially rugged terrain, narrow passages, and vertical shafts are critical for cave ingress and have been demonstrated successfully (Fan et al., 2020; im et al., 2019; Kanellakis et al., 2020; Fan et al., 2019; Colas et al., 2013; Pragr et al., 2019).

(ii) Perception and situational awareness: Recent development in GPS-denied navigation in and 3D mapping of underground environments has enabled fully autonomous motion of robots in caves over 100s of meters distance (Ebadi et al., 2020, Santamaria-Navarro et al., 2019, Daoust et al., 2019, Petricek et al., 2019, Khattak et al., 2019; Zlot et al., 2014; Zhen et al., 2020; Palieri et al. 2020; Tabib et al., 2020).

(iii) Autonomous mission planning and decision-making: Autonomous single-robot and multi-robot coordination and navigation is a critical capability when dealing with largely unknown terrains that are not perceivable by orbiters. This area of autonomy consists of assessing risk, and adapting to the terrain as the robot learns more about the environment. It is an area that has seen huge advancement in the last decade (Otsu et al., 2020, St-Onge et al., 2019, Best et al., 2018, Dang et al., 2019, Reinhart et al., 2020, Tabib et al., 2020).

(iv) Communication: Effective mobile-robot autonomy in self-governing exploration requires reliable communication. Current methods enable a multi-agent robot network to reconfigure itself to various formations based on the science objective in hand to ensure information delivery to the surface (Otsu et al. 2020, Roucek et al., 2020).

\section{SENSOR SYSTEMS DEVELOPED FOR CAVE BIOSIGNATURE IDENTIFICATION}

Boston and colleagues (2001) present a comprehensive inventory of biological techniques used commonly to assess biosignatures associated with microbial communities in caves, many of which are not currently feasible for a remote, robotic planetary mission. Recently, Uckert et al. (2017) proposed an instrument suite for planetary cave exploration which includes:

- Infrared reflectance spectroscopy (wavelength range includes important mineralogical and biogeochemical absorption features)

- Laser-induced breakdown spectroscopy (provides elemental composition of target)

- Scanning electron microscopy and energy dispersive X-ray spectroscopy

In addition to these sensors, a robotic cave deployment vehicle could also employ:

- High-resolution imaging (to record rock surface geometries and assist in navigation)

- Environmental sensors (temperature, atmospheric pressure, etc.)

- Gas sensors (detection of key species, such as methane, water, etc.) 
- Spectral imaging sensors, including imaging in the deep UV to detect organic and microbial features (bioluminescence) and distinguish these from mineral coatings on rock surfaces

Most of these techniques have been or will be deployed as instrument payload on planetary missions and could be adapted for use in a subsurface environment.

\section{TERRESTRIAL FIELD ANALOG STUDIES OF PLANETARY CAVES}

There is increasing interest in the microbiome of lava caves on Earth; studies to date have focused on microbial colony morphology and association with secondary mineralogy (Lavoie et al., 2010), 16S rDNA of bacteria (Lavoie et al., 2017; Kommedal, 2017), and identifying potential energy/chemical nutrient pathways to support microbial life. Table $\mathbf{3}$ summarizes recent and current NASA-supported lava cave astrobiology studies that could inform future planetary investigations.

Other space agencies are preparing for future planetary cave astrobiology missions through studies in terrestrial lava caves. The Canadian Space Agency's Astrobiology Training in Lava Tubes (ATiLT) project (PI R. Léveillé) is educating the next generation of astrobiology scientists through exercises coupling stand-off life detection instruments (LIBS, IR) with laboratory analyses of field microbe-mineral-ice samples collected at Lava Beds National Monument. The European Space Agency's PANGAEA training program is preparing astronauts to become effective partners of astrobiology scientists and mission engineers through exercises in analog settings, including the Corona lava tube in Lanzarote, Spain (Sauro et al., 2020).

Table 3: Selected NASA-funded Terrestrial Analog Studies of Volcanic Caves

\begin{tabular}{|c|c|c|}
\hline Location & Description & References \\
\hline $\begin{array}{l}\text { El Mapais National } \\
\text { Monument NM, USA } \\
\text { Death Valley Nat'I Park CA } \\
\text { USA }\end{array}$ & $\begin{array}{l}\text { Deployed NIR and XRF spectroscopies, XRF, and Deep-UV Raman } \\
\text { instruments on rock-climbing robot. Use of pattern recognition } \\
\text { Al to discriminate macroscopic microbial patterns on lava cave } \\
\text { walls. }\end{array}$ & $\begin{array}{l}\text { NASA PSTAR Free Climber project } \\
\text { (PI A. Parnass) }\end{array}$ \\
\hline \multirow{2}{*}{$\begin{array}{l}\text { Lava Beds National } \\
\text { Monument } \\
\text { CA, USA }\end{array}$} & $\begin{array}{l}\text { Surface GPR (ground-penetrating-radar) to detect known lava } \\
\text { caves (simulating possible activities of the Mars } 2020 \text { payload } \\
\text { instrument RIMFAX (Radar Images for Mars Subsurface } \\
\text { Exploration)), compare with Lidar-mapped caves. Use of hand- } \\
\text { held instruments to study alteration mineralogy in cave interiors. }\end{array}$ & $\begin{array}{l}\text { NASA PSTAR TubeX project } \\
\text { (PI K. Young) } \\
\text { Esmaeili et al. (2017); } \\
\text { Whelley et al. (2017) }\end{array}$ \\
\hline & $\begin{array}{l}\text { Cave astrobiology using rover-borne spectral imaging and } \\
\text { spectrometers. Simulates astrobiology science mission } \\
\text { operational activities with remote team directing rover and } \\
\text { interpreting data. }\end{array}$ & $\begin{array}{l}\text { NASA PSTAR BRAILLE project } \\
\text { (PI J. Blank) } \\
\text { Blank et al. }(2019,2020)\end{array}$ \\
\hline \multirow[b]{2}{*}{$\begin{array}{l}\text { Craters of the Moon } \\
\text { National Monument ID, } \\
\text { USA }\end{array}$} & $\begin{array}{l}\text { Lidar survey of the lava cave as an analog to the exploration of } \\
\text { pits on the Moon and Mars. }\end{array}$ & $\begin{array}{l}\text { NASA SSERVI FINESSE project } \\
\text { (PI J. Heldmann); Neish et al. (2017) }\end{array}$ \\
\hline & $\begin{array}{l}\text { Geochemical techniques to evaluate the occurrence of biological } \\
\text { activity associated with the formation of secondary minerals in } \\
\text { lava caves and other caves. Identified bio/organic compounds } \\
\text { associated with } \mathrm{Na-sulfates.}\end{array}$ & $\begin{array}{l}\text { NASA EXOBIOLOGY } \\
\text { (PI N. Hinman) } \\
\text { Richardson et al. (2013) }\end{array}$ \\
\hline
\end{tabular}

\section{FUTURE LAVA CAVE ASTROBIOLOGY RESEARCH TOPICS}

The past decade has seen significant advances in our ability to detect volcanic caves on the Moon and Mars, and new capabilities are needed to facilitate in situ exploration and characterization. The current DARPA Sub-T highlights underground, autonomous operations as the next frontier for national technology investment and development; planetary cave astrobiology science could benefit greatly from rapid and significant new technology achievements spurred on by this global technology competition. Below are a few of the areas of 
research that could be supported through current and future NASA astrobiology program initiatives. Advancements in these areas could enhance exploration capabilities of many difficult terrains throughout the solar system.

\section{REMOTE SENSING FOR LAVA CAVE DETECTION}

- Machine learning (ML) techniques to process planetary orbital imaging data to identify lava cave skylights (Wagner et al., 2017)

- Remote sensing data fusion (e.g., thermal, gravity, radar, and magnetometry) to improve detection sensitivity of near-surface caverns

- Improved sensor technology + spectral resolution to increase skylight detection success-rates.

- Application of new computational methods for analysis of massively large data sets (planetary imagery) and quantum computing

\section{DEVELOPMENT OF AUTONOMOUS ROBOTICS ABILITIES FOR LAVA CAVE EXPLORATION}

- Sample collection and retrieval capabilities

- Highly mobile robotic units to facilitate access into lava caves

- Sensing and control systems to facilitate autonomous characterization and navigation in subsurface environments

- A reference library of images (or chemistries) of terrestrial cave biosignatures to serve as a training set for future robotics missions with enhanced $\mathrm{Al}$ and $\mathrm{ML}$ capabilities

\section{IMPROVEMENTS IN INSTRUMENTATION FOR AUTONOMOUS IDENTIFICATION AND CHARACTERIZATION OF BIOSIGNATURES}

- Low-mass, power, and volume sample preparation and instrumental techniques capable of onboard analysis of organic molecules/compounds at low detection thresholds

- In situ microstructural/textural analysis capabilities of mineral surfaces

- Rover mounted active sensors such as Light Detection and Ranging (LiDAR) to see while inside caves and collect quantitative topographic and reflectance data for science and engineering

REFERENCES (link to expanded reference list here)

Agha-mohammadi, A., et al. (2019) Team CoSTAR, http://costar.jpl.nasa.gov.

Aldrich, J. B et al. (2006) Proc. 45th IEEE Conf. Decision Control, pp. 2300-2306.

Allen, C.C. (2009) Geological Soc. Am. Abstr. 41:192.

Bell, E., et al. (2020) 2020 NASA Explor. Sci. Forum, NESF2020-005.

Best, G. et al. (2018) Autonomous Robots, 42(4), 715-738.

Blair, D.M., et al. (2017) Icarus 282:47-55.

Blank, J.G. (2020) Intl. Planet. Cave Conf. 3: 1047.

Blank J.G. (2019) Am. Geophys. U. Fall Mtg., No. P44B-09.

Boston, P.J., et al. (2001) Astrobiology 1:25-55.

Chappaz, L., et al. (2017) Geophys. Res. Lett. 44:105-112.

Colas, F., et al. (2013) Proc. IEEE Intl. Conf. Intelligent Robots Sys. (IROS), 722-727.

Crown, D.A., et al. (2019) Lunar \& Planetary Science Conference 50:1417.

Cushing, G.E. et al. (2015) J. Geophys. Res. Planets 120: 1023-1043.

Cushing, G.E., et al. (2007) Geophys. Res. Lett. 34:L17201.

Daga A., et al. (2013) Planetary Sciences Decadal Survey 2013-2022 White Paper, 7p.

Dang T., et al. (2019) IEEE/RSJ Int.I Conf. Intel. Robots Systems (IROS), pp. 3105-3112.

Daoust, T., et al. (2016) Proc. 13th Conf. Computer Robot Vision (CRV).

DARPA (2018) The DARPA Subterranean Challenge, online, https://www.subtchallenge.com/. 
Ebadi K. (2020) IEEE Intl. Conf. Robotics Automation (ICRA), arXiv:2003.01744.

Esmaeili, S., et al. (2017) 2017 AGU Fall Mtg., NS23A-0021.

Fan D. D. et al. (2020) IEEE International Conference on Robotics and Automation (ICRA).

Fan, D.D. et al. (2019) IEEE/RSJ Intl. Conf. Intel. Robots Sys.

Garry, W.B., et al. (2017) Lunar Planet. Sci. Conf. 48:1207.

Furutani, K. (2016) Int. J. Auto. Tech. 10: 584-590.

Gebara, C. A. et al (2019) AlAA Scitech 2019 Forum, p. 0868.

Greeley, R. (1971) The Moon 3:289-314.

Haruyama, J., et al. (2009) Geophys. Res. Lett. 36:L21206.

Hockman, B., et al. (2016) Intl. Symp. Exper. Robotics, p. 752-763.

Jung, J., et al. (2014) J. Astron. Space Sci. 31:141-144.

Jung, J., et al. (2016) J. Astron. Space Sci. 33:21-28.

Kaku, T., et al. (2017) Geophys. Res. Lett. 44:10,155-10,161.

Kalita, H., et al. (2017) Proc. 40 ${ }^{\text {th }}$ Ann. AAS Guid. Nav. Control Conf., 12 p.

Kanellakis C. et al. (2020) IFAC world congress 2020.

Khattak S. et al. (2019) Journal of Field Robotics, 2019, pp. 1-28.

Kim S. et. al (2019) IEEE Robotics Automation Lett. (RA-L) 4:2493-2500.

Kommedal, E.G. (2017MS Thesis, U. Stavanger, 89 p.

Lavoie, K.H., et al. (2010) Geomicrobiology, S.K. Jain et al. eds., p. 1-45.

Lavoie K.H., et al. (2017) PLoS ONE 12:e0169339.

Léveillé, R.J. and S. Datta (2010) Planet. Space Sci. 58:592-598.

Martins, Z., et al. (2017) Space Sci. Rev. 209:43-81.

Neish, C.D., et al. (2017) Icarus 281: 73-89.

Nesnas, I. A. D., et al. (2008) Proc. IEEE Aero. Conf., 1-11.

Nilsson, P. et al. (2018) Robotics: Sci. \& Systems (RSS).

Otsu K. et al (2020) IEEE Aerospace Conference, Big Sky, MT.

Parness, A., et al. (2017) IEEE Intl. Conf. Robot. Auto., 5467-5473.

Paulsen, G. L., et al. (2005) Proc. IEEE Int. Conf. Robot. Auto., 721-726.

Peterson, D.W., R.T. Holcomb, R.I. Tilling, and R.L. Christiansen (1994) Hawaii Bull. Volcanol. 56:343-360.

Petříček T., et al. (2019) Journal of Field Robotics. 36(4), pp 696-709.

Prágr, M. et al. (2019) Robotics: Sci. \& Systems (RSS).

Reinhart R. et al. (2020) IEEE Intl. Conf. Robotics Automation (ICRA).

Richardson, C.D., et al. (2013) Intl. J. Astrobio. 12:357-368.

Robinson, M., et al. (2012) Planet. Space Sci. 69:18-27. S

Sauro, F., et al. (2020) $3^{\text {rd }}$ Planet Caves Workshop, no. 1055.

Sitti, M., \& Fearing, R. (2003) Proc. IEEE Int. Conf. Robot. Auto, 1164-1170.

Rouček, T. et al. (2020) Model. Simulation Autonomous Sys. (MESAS), pp. 274-290.

Santamaria-Navarro, A., et al. (2019) Intl. Symposium Robotics Res. (ISRR).

Sasaki, T., et al. (2020) IEEE Robotics Automation Letters (RA-L) 5:2123-21300.

Sauro, F., et al. (2020) International Planetary Caves Conf. 3: 1055.

Slank, R.A. (2016) M.S. thesis, U. Texas El Paso, 124 p.

Sood, R., et al. (2016) $26^{\text {th }}$ AAS/AIAA Space Flight Mech. Mtg., 15 p.

St-Onge, et al. (2019) IEEE Robotics \& Automation Magazine, 27(2), 159-168.

Tabib, W., et al. (2020) arXiv preprint arXiv:2003.13883.

Thangavelautham, J., et al. (2014) Proc. $2^{\text {nd }}$ Intl. Work. Instr. Planet. Missions, 4 p.

Uckert, K., et al. (2017) Astrobiology 17:1203-1218.

Wagner, R.V., et al. (2017) 3rd Planet. Data Workshop, 7074.

Walker, J., et al. (2015) Proc. Field Service Robot., 1-15.

Whelley, P., et al. (2017) 2017 AGU Fall Mtg., T44D-04.

Wong, U., and R. Whitaker (2015) $2^{\text {nd }}$ Intl. Planet. Caves Conf., 9031.

Wynne, J.J., et al. (2008) Earth Planet. Sci. Lett. 272:240-250.

Zhen, W., et al. (2020) LISS Int.I Conf. Robotics Autonomation.

Zlot et al. (2014) Journal of Cave and Karst Studies, vol. 76, no. 3. 